\title{
Exposure-age constraints on the extent, timing and rate of retreat of the last Irish Sea ice stream
}

\author{
Danny McCarroll a , John O. Stone ${ }^{\mathrm{b}}$, Colin K. Ballantyne ${ }^{\mathrm{c}, *}$, James D. Scourse $^{\mathrm{d}}$, L. Keith Fifield ${ }^{\mathrm{e}}$, \\ David J.A. Evans ${ }^{\mathrm{f}}$, John F. Hiemstra ${ }^{\text {a }}$ \\ a School of the Environment and Society, Swansea University, Singleton Park, Swansea SA2 8PP, Wales, UK \\ ${ }^{\mathrm{b}}$ Department of Earth and Space Sciences and Quaternary Research Center, University of Washington, Box 351310, Seattle WA 98195-1310, USA \\ ${ }^{\mathrm{C} S}$ School of Geography and Geosciences, University of St Andrews, Fife KY16 9AL, Scotland, UK \\ ${ }^{\mathrm{d}}$ School of Ocean Sciences, College of Natural Sciences, Bangor University, Menai Bridge, Anglesey, LL59 5AB, Wales, UK \\ ${ }^{\mathrm{e}}$ Department of Nuclear Physics, Research School of Physics and Engineering, Australian National University, ACT 0200, Australia \\ ${ }^{\mathrm{f}}$ Department of Geography, Durham University, South Road, Durham DH1 3LE, UK
}

\section{A R T I C L E I N F O}

\section{Article history:}

Received 8 December 2009

Received in revised form

30 March 2010

Accepted 1 April 2010

\begin{abstract}
A B S T R A C T
We report 23 cosmogenic isotope exposure ages $\left({ }^{10} \mathrm{Be}\right.$ and $\left.{ }^{36} \mathrm{Cl}\right)$ relating to the maximum extent and deglaciation chronology of the Irish Sea Ice Stream (ISIS), which drained the SW sector of the last British-Irish Ice Sheet. These show that the ISIS failed to reach the Preseli Hills of North Pembrokeshire yet extended southwards to impinge on northern Isles of Scilly $\left(50^{\circ} \mathrm{N}\right)$ during the last glacial maximum. Four samples from western Anglesey demonstrate deglaciation of the southern Irish Sea Basin by c. 20-18 ka, and two from the Llŷn Peninsula in northwest Wales, if valid, suggest deglaciation by c. 23-22 ka followed by gradual oscillatory northwards retreat of the ice margin for over 3000 years. An alternative interpretation of our data suggests that ice reached Scilly as late as $22-21$ ka then retreated $450 \mathrm{~km}$ northwards within the following three millennia, possibly in response to sea level rise and/or intrinsic reorganisation within the last British-Irish Ice Sheet. Samples from upland source areas of the ISIS in NW England and SW Scotland produced exposure ages $\leq 14.3 \mathrm{ka}$, suggesting possible persistence of ice in such areas into the Lateglacial Interstade of $14.7-12.9 \mathrm{ka}$.
\end{abstract}

(c) 2010 Elsevier Ltd. All rights reserved.

\section{Introduction}

During the last glacial maximum (LGM) of 26-21 ka (Peltier and Fairbanks, 2006) the Irish Sea basin was the main conduit for southwards drainage of the British-Irish Ice Sheet (BIIS). Both field evidence (Ó Cofaigh and Evans, 2001a, 2001b; Roberts et al., 2007; Thomas and Chiverrell, 2007) and recent climate-driven thermomechanical coupled models (Boulton and Hagdorn, 2006; Hubbard et al., 2009) indicate development of a high-velocity Irish Sea ice stream (ISIS) that flowed southwards under low shear stresses, at its maximum extent reaching a grounding line SW of the Scilly Isles (Scourse et al., 1990; Scourse, 1991; Scourse and Furze, 2001; Hiemstra et al., 2006). There is geomorphological and sedimentological evidence for the western limit of the ISIS along the south coast of Ireland (Ó Cofaigh and Evans, 2001a, 2001b, 2007), and former ice margin positions have been identified on topographical barriers that lie athwart the direction of flow in north

\footnotetext{
* Corresponding author. Tel.: +44 1334 463907; fax: +44 1334463949.

E-mail address: ckb@st-and.ac.uk (C.K. Ballantyne).
}

Pembrokeshire (Walker and McCarroll, 2001), the Llŷn Peninsula (Young et al., 2002; McCarroll, 2001; Thomas and Chiverrell, 2007) and the Isle of Man (Thomas et al., 2004; Roberts et al., 2007; Fig. 1), but dating control for these former ice limits is weak. Here we present 23 cosmogenic isotope exposure dates that constrain the extent and retreat chronology of the ISIS.

\section{Sample collection and analysis}

Nineteen samples for surface exposure dating were collected from four topographic barriers that lay in the path of the ISIS: the Isles of Scilly, north Pembrokeshire, the Llŷn Peninsula and Anglesey, as well as from upland source areas in Wasdale (NW England) and upper Glen Trool in SW Scotland (Fig. 1; Table 1); the Wasdale and Glen Trool samples were obtained from sites several kilometres outside the limits of the glaciers that formed in these areas during the Loch Lomond (Younger Dryas) Stade of c. 12.9-11.7 ka (Sissons, 1980; Cornish, 1981). Four further samples were collected from sites in the Isles of Scilly and Pembrokeshire that lie outside the inferred LGM limits of the ISIS (Bowen et al. 1986, 2002; Scourse, 1991; Walker and McCarroll, 2001; Hiemstra 


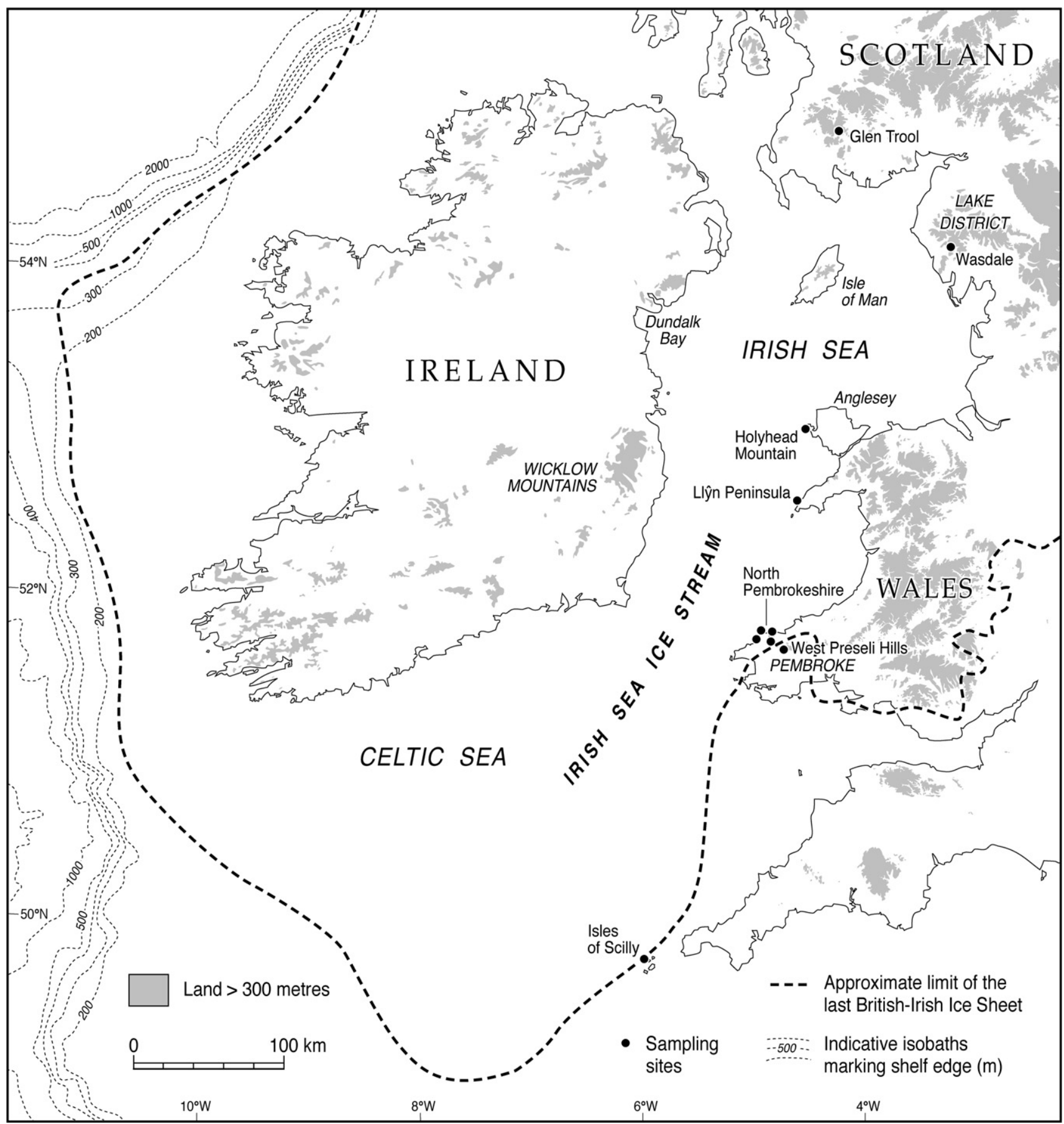

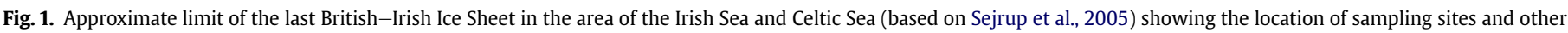
locations mentioned in the text.

et al., 2006). All but five samples were obtained from resistant quartz-rich lithologies (granite, quartzite and vein quartz), allowing ${ }^{10} \mathrm{Be}$ exposure dating of quartz. The exceptions are two samples (PF01, PM-01) from ice-moulded outcrops of volcanic rock in north Pembrokeshire, and three samples (MC-01, MC-02, MC-03) from basaltic and rhyolitic tors on the western Preseli Hills (Mynydd Carningli). These were analysed as whole-rock samples using cosmogenic ${ }^{36} \mathrm{Cl}$. All samples were chiseled from horizontal or near-horizontal bedrock or boulder surfaces, and, where appropriate, corrections for obstruction of incoming cosmic rays by surrounding topography were calculated from skyline measurements. Sample locations are given in Table 1 and discussed further below.

For ${ }^{10} \mathrm{Be}$ analyses, quartz separation and beryllium extraction followed Kohl and Nishiizumi (1992) and Ditchburn and Whitehead (1994); see also Stone (2004). Blanks and carrier contributions to measured ${ }^{10} \mathrm{Be}$ were $<10^{4}$ atoms, necessitating corrections $<1 \%$. Samples for ${ }^{36} \mathrm{Cl}$ dating were crushed to $125-250 \mu \mathrm{m}$ grainsize, leached in deionised water and dilute nitric acid to remove weathering products, then split into aliquots for ${ }^{36} \mathrm{Cl}$ extraction (Stone et al., 1996; Stone, 2001), chloride measurement by isotope dilution and bulk chemical analysis. Chlorine was 
Table 1

Sample location and ${ }^{10} \mathrm{Be}$ analytical data.

\begin{tabular}{|c|c|c|c|c|c|c|c|c|}
\hline Sample & $\begin{array}{l}\text { OS Grid } \\
\text { Reference }\end{array}$ & Latitude $\left({ }^{\circ} \mathrm{N}\right)$ & Longitude $\left({ }^{\circ} \mathrm{W}\right)$ & Altitude $\mathrm{m}$ OD & Thickness mm & Density $\mathrm{g} \mathrm{cm}^{-3}$ & $\begin{array}{l}\text { Shielding } \\
\text { correction }\end{array}$ & $\begin{array}{l}{\left[{ }^{10} \mathrm{Be}\right]} \\
10^{5} \text { atoms }{ }^{-1}\end{array}$ \\
\hline \multicolumn{9}{|c|}{ Sites inside the LGM glacial limit } \\
\hline GT-01 & NX438821 & 55.109 & 4.449 & 340 & 38 & 2.65 & 0.998 & $0.922 \pm 0.039$ \\
\hline GT-2.1 & NX437816 & 55.105 & 4.450 & 390 & 15 & 2.65 & 1.000 & $1.009 \pm 0.020^{*}$ \\
\hline GT-2.2 & NX437816 & 55.105 & 4.450 & 390 & 12 & 2.65 & 1.000 & $0.999 \pm 0.031$ \\
\hline GT-03 & NX439815 & 55.104 & 4.447 & 390 & 28 & 2.65 & 1.000 & $0.904 \pm 0.026^{*}$ \\
\hline \multicolumn{9}{|c|}{ Wasdale, SW Lake District } \\
\hline W-13 & NY153063 & 54.445 & 3.307 & 190 & 16 & 2.65 & 0.896 & $0.739 \pm 0.020$ \\
\hline \multicolumn{9}{|c|}{ Holyhead Mountain, Anglesey, NW Wales } \\
\hline HM-01 & SH215808 & 53.294 & 4.679 & 210 & 13 & 2.65 & 1.000 & $1.269 \pm 0.041$ \\
\hline HМ-2.1 & SH216808 & 53.294 & 4.679 & 205 & 10 & 2.65 & 0.997 & $1.104 \pm 0.032$ \\
\hline HM-2.2 & SH216808 & 53.294 & 4.679 & 205 & 10 & 2.65 & 0.999 & $1.165 \pm 0.044$ \\
\hline HM-03 & SH216808 & 53.294 & 4.679 & 200 & 10 & 2.65 & 0.999 & $1.143 \pm 0.037$ \\
\hline HM-04 & SH216808 & 53.294 & 4.679 & 190 & 10 & 2.65 & 0.996 & $1.075 \pm 0.025^{*}$ \\
\hline \multicolumn{9}{|c|}{ Mynedd Mawr, Lleyn Peninsula, NW Wales } \\
\hline MM-01 & SH141259 & 52.798 & 4.757 & 135 & 28 & 2.65 & 0.999 & $1.282 \pm 0.031$ \\
\hline MM-02 & SH142261 & 52.800 & 4.756 & 125 & 33 & 2.65 & 1.000 & $1.193 \pm 0.037$ \\
\hline \multicolumn{9}{|c|}{ Pembroke, SW Wales } \\
\hline CF-01 & SM977376 & 52.000 & 4.947 & 130 & 19 & 2.65 & 1.000 & $2.007 \pm 0.053$ \\
\hline $\mathrm{CO}-01$ & SM889380 & 51.999 & 5.078 & 119 & 15 & 2.65 & 0.998 & $1.881 \pm 0.081$ \\
\hline PF-01 & SM999374 & 51.998 & 4.915 & 95 & 62 & 2.65 & 1.000 & ${ }^{36} \mathrm{Cl}$ analysis \\
\hline PM-01 & SM883396 & 52.013 & 5.085 & 88 & 40 & 2.65 & 1.000 & ${ }^{36} \mathrm{Cl}$ analysis \\
\hline \multicolumn{9}{|c|}{ Scilly Isles } \\
\hline SC-1B & SV922177 & 49.980 & 6.293 & 20 & 77 & 2.65 & 1.000 & $3.304 \pm 0.093^{*}$ \\
\hline SC-07 & SV903170 & 49.972 & 6.320 & 20 & 32 & 2.65 & 1.000 & $3.896 \pm 0.077^{*}$ \\
\hline SC-08 & SV874163 & 49.965 & 6.360 & 15 & 120 & 2.65 & 1.000 & $0.974 \pm 0.033^{*}$ \\
\hline \multicolumn{9}{|c|}{ Sites outside the LGM glacial limit } \\
\hline \multicolumn{9}{|c|}{ Scilly Isles, outside glacial limit } \\
\hline SC-06 & SV913095 & 49.905 & 6.300 & 15 & 64 & 2.65 & 1.000 & $5.568 \pm 0.133^{*}$ \\
\hline \multicolumn{9}{|c|}{ West Preseli Hills, Pembroke, SW Wales } \\
\hline MC-01 & SN052374 & 52.000 & 4.838 & 290 & 30 & 2.65 & 1.000 & ${ }^{36} \mathrm{Cl}$ analysis \\
\hline MC-02 & SN055372 & 51.998 & 4.833 & 330 & 63 & 2.65 & 0.975 & ${ }^{36} \mathrm{Cl}$ analysis \\
\hline MC-03 & SN054365 & 51.992 & 4.835 & 295 & 36 & 2.65 & 1.000 & ${ }^{36} \mathrm{Cl}$ analysis \\
\hline
\end{tabular}

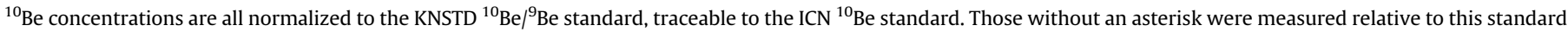

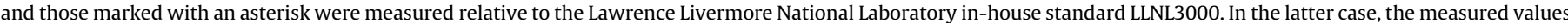

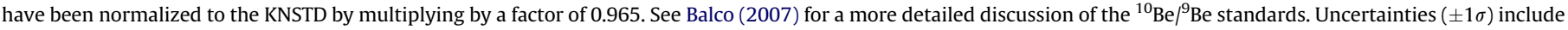
all known sources of analytical error.

analysed for ${ }^{36} \mathrm{Cl}$ using the 14UD accelerator at the Australian National University (Fifield et al., 2010). Procedural blanks run in parallel had ${ }^{36} \mathrm{Cl} / \mathrm{Cl}$ ratios $<10^{-15}\left(\right.$ c. $10^{4}$ atoms $\left.{ }^{36} \mathrm{Cl}\right)$, requiring blank corrections $\leq 1 \%$. Chloride concentrations were measured by isotope dilution with ${ }^{37} \mathrm{Cl}$ on $0.5-1 \mathrm{~g}$ aliquots of crushed rock. Whole-rock chemical compositions were measured by X-ray fluorescence. Trace element neutron producers ( $U$ and $T h$ ) and absorbers (B, Sm, Gd) were analysed by ICP-MS.

We used the CRONUS online calculator (Balco, 2007; Balco et al., 2008 ) to calculate ${ }^{10} \mathrm{Be}$ exposure ages. ${ }^{10} \mathrm{Be}$ production rates are affected by altitude, and both latitudinal and temporal variations in the Earth's magnetic field. The CRONUS calculator allows determination of exposure ages based on four scaling models (De, Du, Li and $\mathrm{Lm}$ ) that correct for these effects. These models account for time variation in ${ }^{10} \mathrm{Be}$ production rate and produce better agreement with high-precision calibration measurements than the original scaling factors of Lal (1991). Differences between exposure ages calculated with the four models range from $3.9 \%$ to $4.6 \%$. To bracket the range of exposure age outcomes, Table 2 shows ages calculated using the Li model (Lifton et al., 2005), which yields the youngest ages, and the Du model (Dunai, 2001), which gives the oldest ages. As concentration of cosmogenic ${ }^{10} \mathrm{Be}$ diminishes with depth, post-exposure erosion of rock surfaces results in underestimation of exposure age (Gosse and Phillips, 2001). To accommodate this effect, we calculated exposure ages for assumed erosion rates $(\varepsilon)$ of 0 and $1 \mathrm{~mm} \mathrm{ka}^{-1}$, the latter representing a reasonable upper limit for most quartz-rich igneous and metamorphic rocks (André, 2002; Nicholson, 2009). We adopt the convention that the youngest possible age is represented by Li scaling with $\varepsilon=0$, and the oldest by Du scaling with $\varepsilon=1 \mathrm{~mm} \mathrm{ka}^{-1}$, and cite both ages with accompanying $\pm 1 \sigma$ external (total) uncertainties (Table 2 ). The difference between ages calculated using $\varepsilon=0$ and $\varepsilon=1 \mathrm{~mm} \mathrm{ka}^{-1}$ is $1-2 \%$ of sample age for all ages between 12.5 and $25.0 \mathrm{ka}$, and calculation of $\varepsilon=2 \mathrm{~mm} \mathrm{ka}^{-1}$ (not shown in Table 2) adds a further $1-2 \%$ to ages within the same range. The ${ }^{36} \mathrm{Cl}$ exposure ages are based on production rates scaled using the original correction factors of Lal (1991) for spallation and muon capture reactions, without adjustment for past magnetic field variation. By analogy with ${ }^{10} \mathrm{Be}$, these uncorrected ${ }^{36} \mathrm{Cl}$ exposure ages are likely to be 5-7\% younger than ages that would be obtained from a variable production rate calculation. For samples collected outside the inferred ice limits (MC-01, MC-02, MC-03) this difference is of no importance; for sample PF-01, it would bring the ${ }^{36} \mathrm{Cl}$ age into closer agreement with the ${ }^{10} \mathrm{Be}$ ages of samples CF-01 and CO-01. Full details of ${ }^{36} \mathrm{Cl}$ production rates and of the underlying calibrations are given in the online data (http://depts.washington.edu/ cosmolab/data). Table 3 gives uncorrected exposure ages assuming $\varepsilon=0$, together with the minimum possible ages of $\mathrm{Cl}$-rich samples for which any surface erosion would lower the apparent age (cf. Liu et al., 1994). Mean ages shown in Table 2 and cited below are weighted means with weighting factor $1 / \sigma_{i}^{2}$ where $\sigma_{i}$ is the internal (analytical) uncertainty. Weighted means rather than 
Table 2

${ }^{10} \mathrm{Be}$ exposure ages.

\begin{tabular}{|c|c|c|c|c|c|c|}
\hline \multirow[t]{2}{*}{ Sample } & \multicolumn{3}{|c|}{ Lifton (Li) scaling, $\varepsilon=0$} & \multicolumn{3}{|c|}{ Dunai (Du) scaling, $\varepsilon=1 \mathrm{~mm} \mathrm{ka}^{-1}$} \\
\hline & $\begin{array}{l}\text { Exposure } \\
\text { age (ka) }\end{array}$ & $\begin{array}{l}\text { Internal } \\
\text { uncertainty (ka) }\end{array}$ & $\begin{array}{l}\text { External } \\
\text { uncertainty (ka) }\end{array}$ & $\begin{array}{l}\text { Exposure } \\
\text { age (ka) }\end{array}$ & $\begin{array}{l}\text { Internal } \\
\text { uncertainty (ka) }\end{array}$ & $\begin{array}{l}\text { External } \\
\text { uncertainty (ka) }\end{array}$ \\
\hline \multicolumn{7}{|c|}{ Sites inside LGM ice limit } \\
\hline GT-01 & 13.38 & 0.57 & 1.44 & 14.11 & 0.60 & 1.79 \\
\hline GT-2.1 & 13.54 & 0.27 & 1.37 & 14.29 & 0.29 & 1.73 \\
\hline GT-2.2 & 13.53 & 0.43 & 1.40 & 14.28 & 0.46 & 1.76 \\
\hline GT-03 & 12.30 & 0.36 & 1.27 & 12.95 & 0.38 & 1.59 \\
\hline GT weighted mean & 13.20 & 0.18 & 1.32 & 13.92 & 0.19 & 1.68 \\
\hline GT wm (less GT-03) & 13.51 & 0.21 & 1.35 & 14.26 & 0.23 & 1.73 \\
\hline \multicolumn{7}{|l|}{ Wasdale, NW England } \\
\hline$W-13$ & 13.50 & 0.37 & 1.39 & 14.22 & 0.39 & 1.74 \\
\hline \multicolumn{7}{|c|}{ Holyhead Mountain, Anglesey. NW Wales } \\
\hline HM-01 & 20.48 & 0.66 & 2.14 & 21.79 & 0.72 & 2.72 \\
\hline HM-2.1 & 17.94 & 0.51 & 1.85 & 19.03 & 0.55 & 2.35 \\
\hline HM-2.2 & 18.88 & 0.72 & 2.01 & 20.05 & 0.78 & 2.53 \\
\hline HM-03 & 18.62 & 0.61 & 1.94 & 19.76 & 0.65 & 2.46 \\
\hline HM-04 & 17.71 & 0.43 & 1.80 & 18.77 & 0.45 & 2.29 \\
\hline HM weighted mean & 18.44 & 0.25 & 1.84 & 19.56 & 0.27 & 2.36 \\
\hline HM wm (less HM-01) & 18.11 & 0.27 & 1.81 & 19.20 & 0.29 & 2.32 \\
\hline \multicolumn{7}{|c|}{ Mynydd Mawr, Llŷn Peninsula, NW Wales } \\
\hline MM-01 & 22.55 & 0.56 & 2.30 & $23.57^{*}$ & 0.58 & 2.84 \\
\hline MM-02 & 21.27 & 0.66 & 2.21 & 22.62 & 0.71 & 2.81 \\
\hline MM weighted mean & 22.01 & 0.43 & 2.22 & 23.19 & 0.45 & 2.82 \\
\hline \multicolumn{7}{|c|}{ North Pembroke coast, SW Wales } \\
\hline CF-01 & 35.28 & 0.93 & 3.63 & 38.04 & 1.04 & 4.77 \\
\hline $\mathrm{CO}-01$ & 33.37 & 1.45 & 3.62 & 35.93 & 1.61 & 4.67 \\
\hline \multicolumn{7}{|c|}{ Scilly Isles, south Celtic Sea } \\
\hline SC-1B & 68.03 & 1.94 & 7.09 & 75.48 & 2.29 & 9.90 \\
\hline SC-07 & 77.55 & 1.55 & 7.95 & 86.93 & 1.86 & 11.4 \\
\hline SC-08 & 20.93 & 0.71 & 2.19 & 22.13 & 0.76 & 2.77 \\
\hline \multicolumn{7}{|c|}{$\begin{array}{l}\text { Sites outside LGM ice limit } \\
\text { Scilly Isles, south Celtic Sea }\end{array}$} \\
\hline SC-06 & 114.9 & 2.82 & 12.0 & 133.8 & 3.73 & 18.6 \\
\hline
\end{tabular}

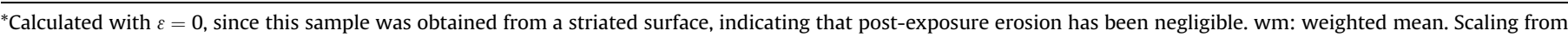

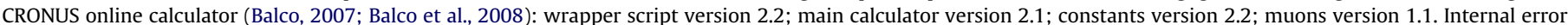

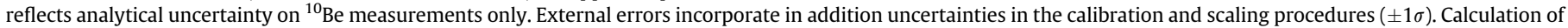
ages using $\varepsilon=2 \mathrm{~mm} \mathrm{ka}^{-1}$ adds $1-2 \%$ for ages between $12 \mathrm{ka}$ and $25 \mathrm{ka}$.

arithmetic means are appropriate because analytical uncertainties vary by up to a factor of two among samples from the same site. Production rate and scaling uncertainties, which amount to 9.9\% and $12 \%$ respectively for Li and Du scaling (Balco, 2007; Balco et al., 2008), were added in quadrature to the internal errors to obtain the total (external) uncertainties on the weighted means. Tests of

Table 3

${ }^{36} \mathrm{Cl}$ exposure ages.

\begin{tabular}{|c|c|c|c|}
\hline Sample & $\begin{array}{l}\text { Internal } \\
\text { uncertainty (ka) }\end{array}$ & $\begin{array}{l}\text { Conventional } \\
\text { exposure age (ka) }\end{array}$ & $\begin{array}{l}\text { Minimum possible } \\
\text { exposure age (ka) }\end{array}$ \\
\hline \multicolumn{4}{|c|}{$\begin{array}{l}\text { Samples inside the LGM glacial limit } \\
\text { Pembroke, SW Wales }\end{array}$} \\
\hline PF-01 & 1.9 & $33.51 \pm 2.56$ & $33.44 \pm 2.56$ \\
\hline PM-01 & 4.4 & $76.82 \pm 7.20$ & $68.13 \pm 6.38$ \\
\hline \multicolumn{4}{|c|}{ Samples outside the LGM glacial limit } \\
\hline MC-01 & 5.0 & $107.1 \pm 7.70$ & $107.1 \pm 7.70$ \\
\hline MC-02 & 8.6 & $152.6 \pm 15.7$ & $142.6 \pm 14.7$ \\
\hline MC-03 & 6.9 & $129.5 \pm 14.1$ & $108.7 \pm 11.9$ \\
\hline
\end{tabular}

Conventional exposure ages assume negligible rock erosion. Minimum possible exposure ages were obtained for samples that show evidence of erosion by calculating production profiles for the combined reactions and solving for the range of exposure ages and steady erosion rates consistent with measured ${ }^{36} \mathrm{Cl}$ concentrations (cf. Phillips et al., 2001). Complete analytical results for these samples can be obtained from the University of Washington Cosmogenic Nuclide Laboratory website:http://depts.washington.edu/cosmolab/data/Irish_Sea_data.html. difference between samples from the same site were performed using the two sample difference of means $(t)$ test, with $\nu=\infty$, differences being tested on the basis of analytical uncertainties (Table 2), as production rate uncertainties affect all samples from similar altitudes at the same site equally.

Additional considerations that affect interpretation of exposure dates are (1) a former cover of sediment may have shielded some sampled surfaces, leading to underestimation of exposure age, and (2) some sampled surfaces may contain ${ }^{10} \mathrm{Be}$ or ${ }^{36} \mathrm{Cl}$ produced by pre-LGM exposure to cosmic radiation. This effect, the result of insufficient glacial erosion during the LGM to remove existing nuclide profiles, is likely to be most problematic in our southernmost samples obtained close to the former margin of the ISIS, from sites where ice cover was thin, flow was divergent and ice cover was of limited duration. Anomalously 'old' exposure ages, resulting from nuclide inheritance are more common in resistant lithologies such as the volcanic rocks of the Pembrokeshire coast (e.g. Stone and Ballantyne, 2006; Ballantyne et al., 2009b).

\section{Results}

\subsection{The Scilly Isles, south Celtic Sea}

A distinct limit of till and soliflucted till derived from the Irish Sea basin and associated with moraine ridges and glacially-eroded 


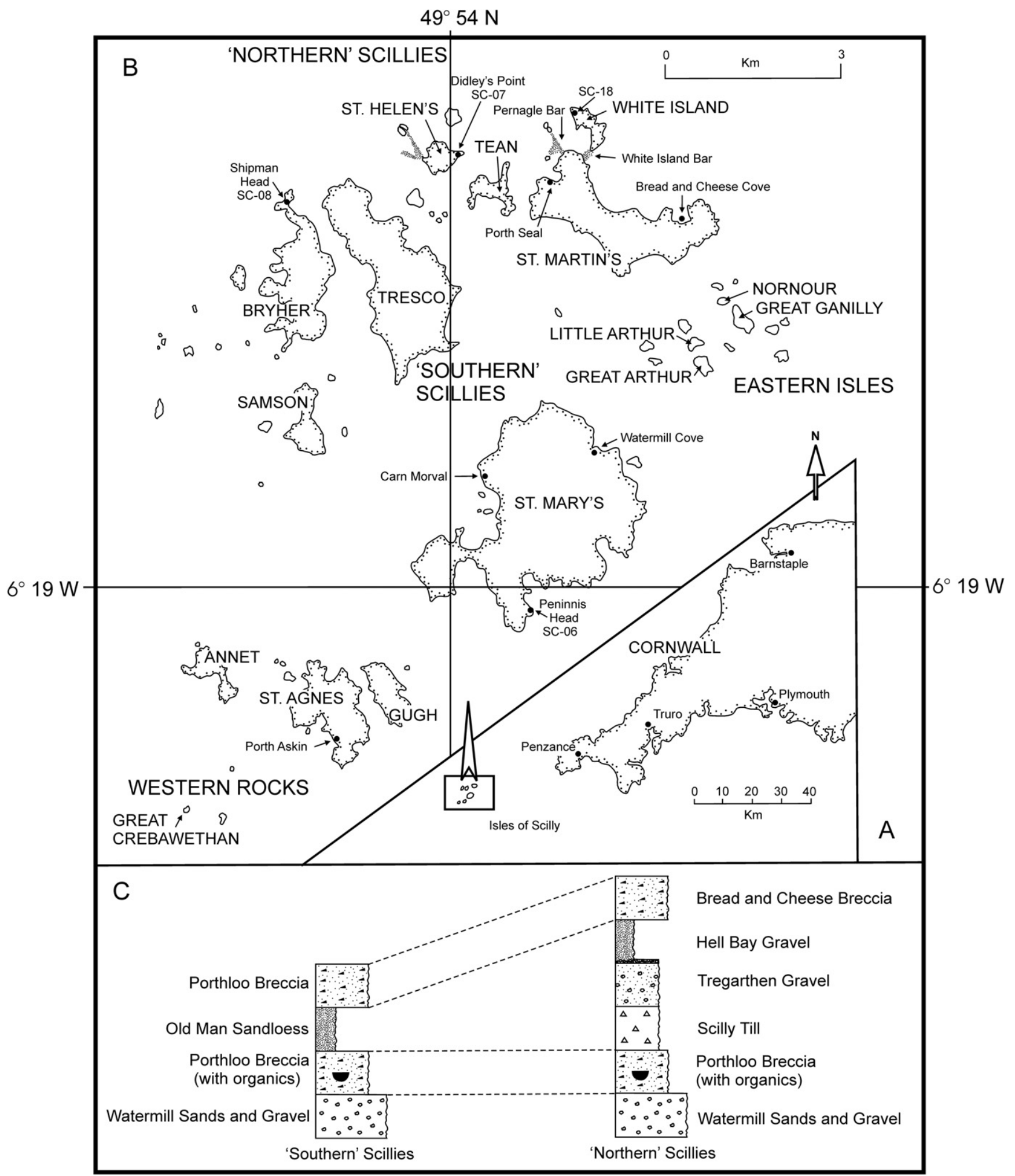

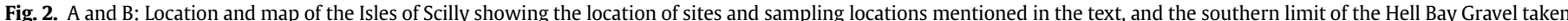

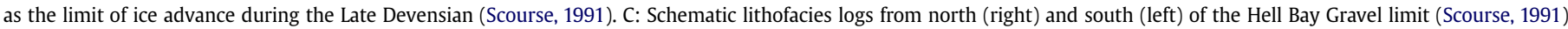

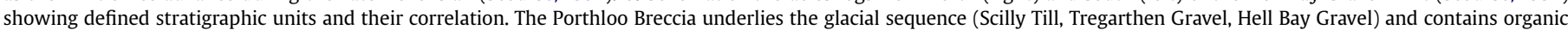

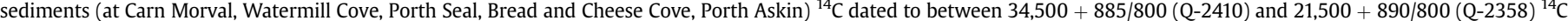

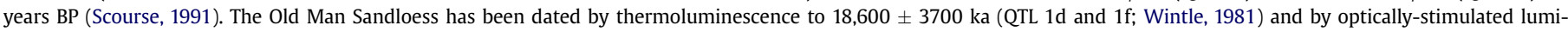
nescence to $20,000 \pm 7000 \mathrm{ka}$ and $26,000 \pm 10,000 / 9000$ (738 al and 741 al; Smith et al., 1990). 
tors was used by Scourse (1991) to define the southernmost extent of the grounded ISIS across the northern part of the Isles of Scilly. Hiemstra et al. (2006) substantiated this inferred glaciation limit when they identified seemingly relatively recent additional moraine ridges and glacitectonic structures in sediments exposed in the northernmost parts of Scilly. TL, OSL and radiocarbon dates relating to the Scilly ice limit on balance support moraine formation and till deposition during the last glacial cycle (Fig. 2; Scourse, 1991; Scourse and Furze, 2001; Hiemstra et al., 2006; Scourse et al., 2006), though this remains controversial (e.g. McCabe, 2008). To test this conclusion, one sample was obtained from outside the
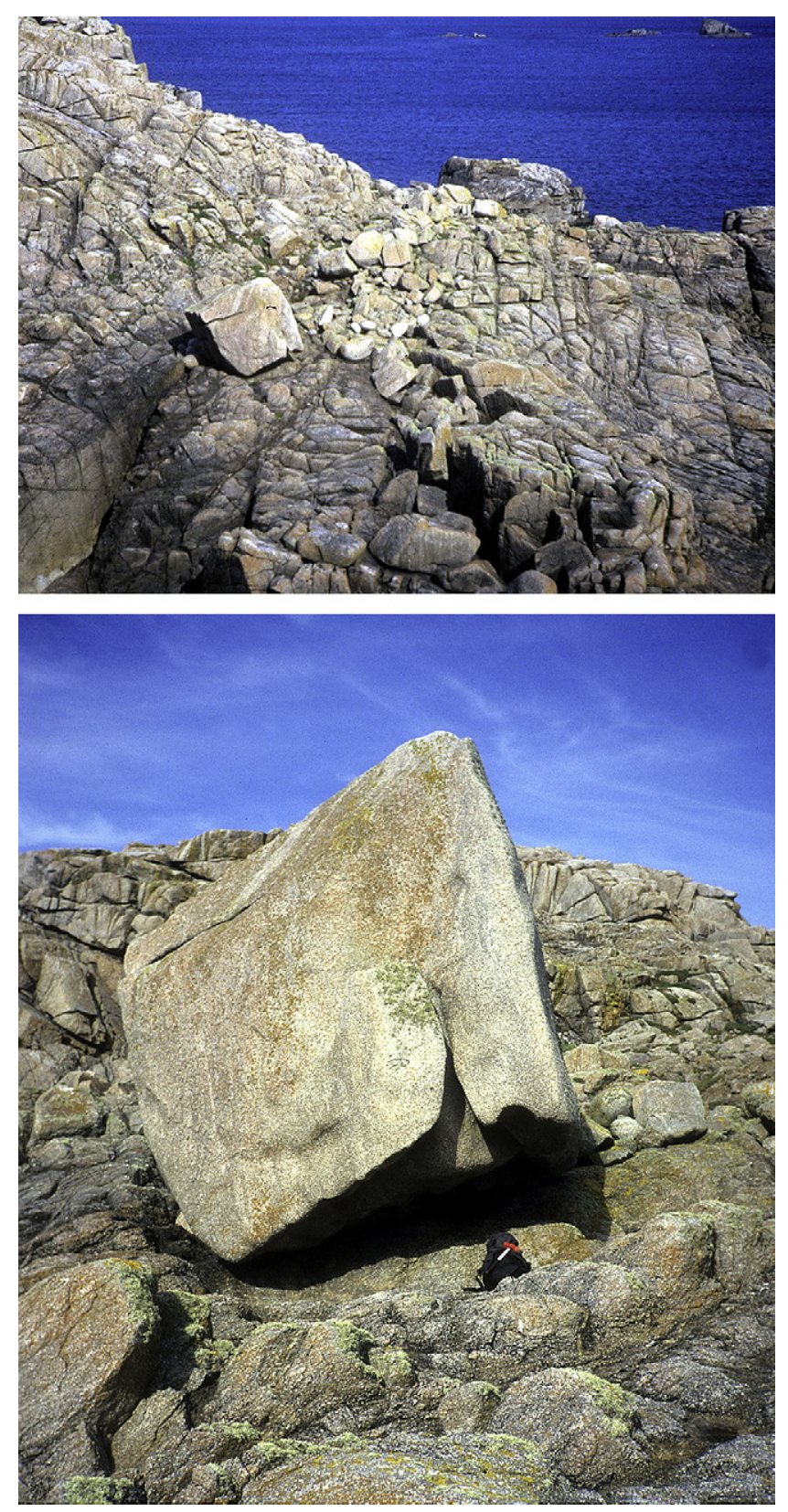

Fig. 3. Upper: boulder moraine located on eroded granite surface, Shipman Head, Bryher, Isles of Scilly (see Fig. 2 for location), viewed looking northeastwards towards the island of Men-a-vaur; the large boulder sampled (SC-08) is clearly visible on the left. Lower: boulder of local granite sampled for ${ }^{10} \mathrm{Be}$ rock exposure dating (sample SC-08), rucksack for scale. Weathering pits and drainage channels are visible on the underside of the boulder indicating that this boulder was probably eroded from a nearby granite tor and inverted during deposition. glacial limit and three inside the limit. Sample SC-06, from a granite tor outside the limit produced a minimum ${ }^{10} \mathrm{Be}$ age of $115 \pm 12 \mathrm{ka}$ to $134 \pm 19 \mathrm{ka}$, consistent with exposure throughout the last glacial cycle. However, two samples (SC-1B, SC-07) from granite outcrops on northern headlands just within the glacial limit also produced pre-LGM exposure ages, of $68.0 \pm 7.1$ to $75.5 \pm 9.9 \mathrm{ka}$ and $77.6 \pm 7.9$ to $86.9 \pm 11.4$ ka respectively. By contrast, a further sample (SC-08) from a boulder inside the glacial limit produced a post-LGM exposure age of $20.9 \pm 2.2$ to $22.1 \pm 2.8 \mathrm{ka}$, consistent with deposition by the last ice sheet. This sample was obtained from the top of a $\sim 9 \mathrm{~m}^{3}$ granite boulder from a moraine on Shipman Head, Bryher (Fig. 3). A network of weathering pits and drainage channels on the underside of the boulder demonstrates that it had been inverted, providing a fresh surface at the time of deposition. However, an incipient drainage network on the top surface implies post-depositional erosion, so the age range for this sample may slightly underestimate true exposure age. We attribute the conflict between the post-LGM age of SC-08 and the ages obtained for SC1B and SC-07 to the effects of nuclide inheritance in the latter, as it is unlikely that glacial erosion could have removed $2-3 \mathrm{~m}$ of bedrock from these sites during the brief period that the ISIS impinged on the Scilly Isles, particularly if southwards extension of ISIS to the Scillies represented a short-lived surge event (Scourse et al., 1990; Hiemstra et al., 2006).

\subsection{The north Pembroke coast, southwest Wales}

Geomorphological evidence (Catt et al., 2006) indicates that the eastern LGM limit of the ISIS lay along the north Pembroke coast (Fig. 1). East of the proposed ice limit, the western Preseli Hills (Mynydd Carningli) show no evidence of glaciation, and the landscape is dominated by tors rising above autochthonous blockfields (Walker and McCarroll, 2001). Closer to the coast, however, rocky knolls are conspicuously ice-scoured and glacial deposits derived from the Irish Sea basin are widespread (Hiemstra et al., 2005). Three samples collected from basaltic tors on the west Preseli Hills (MC-01, MC-02, MC-03) all yielded minimum ${ }^{36} \mathrm{Cl}$ ages $>100 \mathrm{ka}$ (Table 3), consistent with the inference that this area escaped glaciation during the LGM. Two samples (CF-01, CO-01) from icemoulded outcrops on coastal headlands just within the proposed glacial limit produced ${ }^{10} \mathrm{Be}$ ages of $35.3 \pm 3.6$ to $38.0 \pm 4.8 \mathrm{ka}$ and $33.4 \pm 3.6$ to $35.9 \pm 4.7 \mathrm{ka}$ and two further samples (PF-01 and PM$01)$ gave ${ }^{36} \mathrm{Cl}$ ages of $33.5 \pm 2.6 \mathrm{ka}$ and $76.8 \pm 7.2 \mathrm{ka}$. Although three of these ages are internally consistent and all are significantly younger than those obtained from the Preseli tors, all are significantly older than the LGM, and thus conflict with the geomorphological evidence for over-running of the north Pembroke coast by the ISIS during the LGM. We infer that all four ages are augmented by nuclide inheritance due to insufficient removal of bedrock by glacial erosion, and thus provide no information on the timing of ice retreat.

\subsection{The Llŷn peninsula, northwest Wales}

The Llŷn Peninsula forms a major topographic barrier (Fig. 1) crossed by ice-marginal sediment-landform assemblages that reflect oscillatory retreat of the ISIS and decoupling from ice radiating from Snowdonia (McCarroll and Ballantyne, 2000; Thomas and Chiverrell, 2007). Two samples (MM-01 and MM-02) were obtained from ice-scoured quartzite outcrops at Mynydd Mawr near the western end of the peninsula. Sample MM-01 was obtained from a striated surface, indicating that post-exposure erosion has been negligible and thus that the effective age range is $22.6 \pm 2.3 \mathrm{ka}$ (Li scaling, $\varepsilon=0$ ) to $23.6 \pm 2.8 \mathrm{ka}$ (Du scaling, $\varepsilon=0$ ) for this sample. Sample MM-02 yielded exposure ages of $21.3 \pm 2.2 \mathrm{ka}$ 
(Li scaling, $\varepsilon=0$ ) to $22.6 \pm 2.8 \mathrm{ka}$ (Du scaling, $\varepsilon=1 \mathrm{~mm} \mathrm{ka}^{-1}$ ). The exposure ages for the two samples yield a weighted mean age of $22.0 \pm 2.2 \mathrm{ka}$ to $23.2 \pm 2.8 \mathrm{ka}$. Despite the consistency of the two ages, we cannot exclude the possibility of nuclide inheritance, and these ages should be considered maximal for deglaciation of western Llŷn.

\subsection{Holyhead mountain, Anglesey, north Wales}

Five samples of vein quartz (HM-01, HM-2.1, HM-2.2, HM-03, HM-04) collected near the ice-moulded quartzite summit of Holyhead Mountain yielded a fairly closely clustered group of ages with a mean age of $18.4 \pm 1.8$ to $19.6 \pm 2.4 \mathrm{ka}$. However, the greatest individual age in this group (HM-01: $20.5 \pm 2.1$ to $21.8 \pm 2.7 \mathrm{ka}$ ) differs from the weighted mean of all others in the group at $p<0.01$, suggesting that the age obtained for HM-01 may reflect slight nuclide inheritance, and that the mean age of the other four samples ( $18.1 \pm 1.8$ to $19.2 \pm 2.3 \mathrm{ka}$ ) should be considered representative for the timing of deglaciation at this site.

\subsection{Upland source areas: Wasdale, northwest England and Glen Trool, southwest Scotland}

The samples from the two upland source area sites produced much younger exposure ages than the others reported here. Vein quartz from the lee side of a roche moutonnée in Wasdale (sample $\mathrm{W}-13$ ) yielded ${ }^{10} \mathrm{Be}$ exposure ages of $13.5 \pm 1.4 \mathrm{ka}$ to $14.2 \pm 1.7 \mathrm{ka}$, and four samples from the tops of granite boulders in Glen Trool (GT-01, GT-2.1, GT-2.2, GT-03) produced a mean age of $13.2 \pm 1.3 \mathrm{ka}$ to $13.9 \pm 1.7 \mathrm{ka}$. However, the exposure age of sample GT-03 $(12.3 \pm 1.3$ to $13.0 \pm 1.6 \mathrm{ka})$ is significantly younger $(p<0.1)$ than the weighted mean age of the other three Glen Trool samples, possibly reflecting former shielding by sediment cover. We infer that the mean age of the other three samples $(13.5 \pm 1.4$ to $14.2 \pm 1.7 \mathrm{ka}$ ) is more representative for deglaciation of this site.

\section{Discussion}

Although some of the exposure ages reported above (samples SC-1B, SC-07, CF-01, CO-01, PF-01, PM-01) appear to be compromised by nuclide inheritance and others may represent maximal ages for deglaciation (MM-01, MM-02, HM-01), our results allow several conclusions to be drawn regarding the extent and deglaciation chronology of the ISIS. First, the exposure ages obtained for tors on the Preseli Hills and Scilly all exceed $100 \mathrm{ka}$, confirming that these sites lay beyond the limits of the ISIS at the LGM (Scourse, 1991; Hiemstra et al., 2006; Catt et al., 2006). Second, the four youngest samples (HM-2.1, HM2.2, HM-03, HM-04) obtained for Holyhead Mountain yield an uncertainty-weighted mean age of $18.1 \pm 1.8$ to $19.2 \pm 2.3 \mathrm{ka}$, suggesting deglaciation of the southern Irish Sea basin by $18-20 \mathrm{ka}$. This inference is consistent with three ${ }^{10} \mathrm{Be}$ ages averaging $18.8 \pm 1.9 \mathrm{ka}$ to $20.1 \pm 2.4 \mathrm{ka}$ for downwastage of the Wicklow ice dome on the opposite side of the Irish Sea (ages recalculated from Ballantyne et al. (2006)), and with AMS ${ }^{14} \mathrm{C}$ ages that indicate open marine conditions in and NW of Dundalk Bay (Fig. 1) by c. 18.5-19.0 cal ka (McCabe et al., 2005, 2007). Collectively, these dates suggest deglaciation of most of the Irish Sea basin by c. $18-19 \mathrm{ka}$.

Thirdly, the exposure age obtained for the large granite boulder at Shipman Head on Scilly $(20.9 \pm 2.2$ to $22.1 \pm 2.8 \mathrm{ka})$ appears to confirm that the ISIS reached the Scilly Isles during or shortly after the LGM. However, the Shipman Head exposure age and the mean exposure age of $22.0 \pm 2.2 \mathrm{ka}$ to $23.2 \pm 2.8 \mathrm{ka}$ for the two samples obtained from the Llŷn Peninsula appear incompatible (within the limits imposed by the associated uncertainties) as the former site must have been deglaciated before the latter. A maximal age of $c$. 24 cal ka for extension of ice southwards across the Celtic Sea to Scilly is provided by AMS ${ }^{14} \mathrm{C}$ dating of shell fragments incorporated in till deposited by the ISIS along the southern coast of Ireland (Ó Cofaigh and Evans, 2007), and supported by ice-rafted debris with ISIS lithological affinity that occurs in Heinrich layer 2 (c. $24 \mathrm{cal} \mathrm{ka}$ ) in core OMEX-2K obtained from the adjacent continental slope (Scourse et al., 2000, 2009; Haapaniemi et al., 2010). Our dating evidence suggests two possible scenarios. First, if the Shipham Head exposure age is too young but the Llŷn Peninsula ages are valid, it is possible that the ISIS margin reached its southernmost limit around or shortly after $24 \mathrm{ka}$, then retreated rapidly to the central Irish Sea Basin at the latitude of the Llŷn Peninsula. The large difference between the mean exposure age obtained for Llŷn $(22.0 \pm 2.2$ to $23.2 \pm 2.8 \mathrm{ka})$ and that for Holyhead Mountain $(18.1 \pm 1.8$ to $19.2 \pm 2.3 \mathrm{ka}$ ) implies that under this scenario the ice margin then experienced gradual net northwards retreat over a period of roughly 3-4000 years. Some support for this is provided by structural and sedimentological evidence in northern Llŷn for an oscillating ice margin that underwent at least 11 readvances as it retreated northwards towards Anglesey (Thomas and Chiverrell, 2007), though these could have been of short duration. Similar evidence for ice-marginal oscillations occurs on the east coast of Ireland (Thomas and Summers, 1983, 1984; Evans \& Ó Cofaigh, 2003).

If the Shipham Head exposure age is valid and ice impinged on the northern parts of the Scilly Isles at $20.9 \pm 2.2$ to $22.1 \pm 2.8 \mathrm{ka}$, the exposure ages from the Llŷn Peninsula must be regarded as maximal (augmented by nuclide inheritance) and a different scenario unfolds, in which the margin of the ISIS withdrew northwards from Scilly to Anglesey, a distance of $370 \mathrm{~km}$, within about $3 \mathrm{ka}$. Ice-free conditions in Dundalk Bay at c. 19 cal ka (McCabe et al., 2005, 2007) imply northwards retreat of the ice margin of over $450 \mathrm{~km}$ in 2-4 ka. On present evidence, there is no way to distinguish between the two scenarios. Both, however, involve rapid and early northwards retreat of the ISIS ice margin, suggesting that retreat may have been caused or enhanced by rise in relative sea level at the margins of the ISIS (McCabe and Ó Cofaigh, 1996) and/or reflect intrinsic ice sheet instability associated with the development of a fast, low-gradient ice stream (Hubbard et al., 2009).

The exposure ages obtained for samples from source areas of the ISIS in Wasdale $(13.5 \pm 1.4 \mathrm{ka}$ to $14.2 \pm 1.7 \mathrm{ka})$ and Glen Trool (weighted mean age $13.5 \pm 1.4$ to $14.3 \pm 1.7 \mathrm{ka}$ ) suggest possible persistence of ice in these upland valleys during at least the early part of the Lateglacial Interstade ( $\approx$ Greenland Interstade 1 of Lowe et al., 2008; 14.7-12.9 ka), despite rapid summer warming at c. $14.7 \mathrm{ka}$ (Brooks and Birks, 2000). Exposure dating of boulders on moraines in NW Scotland has produced almost identical ages, and also indicates persistence of substantial ice masses during at least the early part of the Lateglacial Interstade (Bradwell et al., 2008; Ballantyne et al., 2009a). The Wasdale and Glen Trool dates suggest that survival of ice cover in upland source areas of the last ice sheet after $c$. 14.3 ka may have been a more widespread phenomenon.

\section{Conclusions}

1. Exposure ages $>100 \mathrm{ka}$ for samples obtained from tors on the Preseli Hills in north Pembroke and south of the inferred glacial limit on the Isles of Scilly confirm that these areas escaped glaciation during the last glacial stage. A single ${ }^{10} \mathrm{Be}$ exposure age of $20.9 \pm 2.2$ ka to $22.1 \pm 2.8$ ka supports the hypothesis that the ISIS impinged on northern Scilly during the LGM.

2. Four ${ }^{10} \mathrm{Be}$ exposure ages for samples obtained from Holyhead Mountain on the westernmost point of Anglesey average of $18.1 \pm 1.8 \mathrm{ka}$ to $19.2 \pm 2.3 \mathrm{ka}$, implying deglaciation of the 
southern Irish Sea Basin by $18-20 \mathrm{ka}$, and consistent with evidence for open marine conditions around Dundalk Bay in eastern Ireland by $18.5-19.0 \mathrm{cal} \mathrm{ka}$. These dates imply that the margin of the ISIS retreated $450 \mathrm{~km}$ northwards following the LGM, possibly reflecting mass loss by accelerated calving as relative sea level rose (cf. Brooks et al., 2008) and/or intrinsic ice sheet instability following the development of a fast lowgradient ice stream that drained ice southwards through the Irish Sea basin into the area of the Celtic Sea (Roberts et al., 2007; Evans et al., 2009).

3. Two scenarios are proposed for ISIS ice margin retreat. Exposure ages obtained for ice-moulded rock outcrops on the Llŷn Peninsula average $22.0 \pm 2.2$ ka to $23.2 \pm 2.8 \mathrm{ka}$, suggesting rapid retreat of the ISIS ice margin from its southernmost limit to the latitude of Llŷn, followed by a period of gradual oscillatory retreat lasting over 3000 years. Alternatively, if the Llŷn dates represent maxima, the exposure age of $20.9 \pm 2.2 \mathrm{ka}$ to $22.1 \pm 2.8 \mathrm{ka}$ for a boulder on Scilly implies evacuation of ice from most of the Irish Sea basin within the period c. 22-19 ka.

4. Five samples from upland source areas of the ISIS produced exposure ages $\leq 14.3 \mathrm{ka}$, suggesting possible persistence of ice during the early part of the Lateglacial Interstade.

\section{Acknowledgements}

Fieldwork and analytical costs associated with this research were supported by grants from NERC (NER/B/S/2001/0919), the Carnegie Trust for the Universities of Scotland and the Quaternary Research Association. We thank Graeme Sandeman for drafting Fig. 1, Justin Brooks and Joy Laydbak for help with sample preparation, and Derek Fabel and Richard Chiverrell for thorough and constructive reviews.

\section{References}

André, M.-F., 2002. Rates of postglacial rock weathering on glacially-scoured outcrops, Abisko-Riksgränsen area, $\left(68^{\circ} \mathrm{N}\right)$. Geografiska Annaler 84A, 139-150.

Balco, G., 2007. CRONUS-Earth online calculators, version 2.0. Available at: http:// hess.ess.washington.edu.math/ [August 2009].

Balco, G., Stone, J.O., Lifton, N.A., Dunai, T.J., 2008. A complete and easily accessible means of calculating surface exposure ages or erosion rates from Be-10 and Al26 measurements. Quaternary Geochronology 3, 174-195.

Ballantyne, C.K., McCarroll, D., Stone, J.O., 2006. Vertical Dimensions and age of the Wicklow Mountains ice dome, eastern Ireland, and implications for the extent of the last Irish ice sheet. Quaternary Science Reviews 25, 2048-2058.

Ballantyne, C.K., Schnabel, C., Xu, S., 2009a. Readvance of the last British-Irish ice sheet during Greenland Interstade 1 (GI-1): the Wester Ross readvance, NW Scotland. Quaternary Science Reviews 28, 783-789.

Ballantyne, C.K., Stone, J.O., Fifield, L.K., 2009b. Glaciation and deglaciation of the SW Lake District, England, implications of cosmogenic ${ }^{36} \mathrm{Cl}$ exposure dating. Proceedings of the Geologists' Association 120, 139-144.

Boulton, G.S., Hagdorn, M., 2006. Glaciology of the British Isles Ice Sheet during the last glacial cycle: form, flow, streams and lobes. Quaternary Science Reviews 25, 3359-3390.

Bowen, D.Q., Rose, J., McCabe, A.M., Sutherland, D.G., 1986. Correlation of Quaternary glaciations in England, Ireland, Scotland and Wales. Quaternary Science Reviews 5, 299-340.

Bowen, D.Q., Phillips, F.M., McCabe, A.M., Knutz, C., Sykes, G.A., 2002. New data for the last glacial maximum in Great Britain and Ireland. Quaternary Science Reviews 21, 89-102.

Bradwell, T., Fabel, D., Stoker, M.S., Mathers, H.E., McHargue, L., Howe, J., 2008. Ice caps existed throughout the Lateglacial Interstadial in northern Scotland. Journal of Quaternary Science 23, 401-407.

Brooks, A.J., Bradley, S.L., Edwards, R.J., Milne, G.A., Horton, B., Shennan, I., 2008. Postglacial relative sea-level observations from Ireland and their role in glacial rebound modelling. Journal of Quaternary Science 23, 175-192.

Brooks, S.J., Birks, H.J.B., 2000. Chironomid-inferred Late-glacial air temperatures at Whitrig Bog, southeast Scotland. Journal of Quaternary Science 15, 759-764.

Catt, J.A., Gibbard, P.L., Lowe, J.J., McCarroll, D., Scourse, J.D., Walker, M.J.C., Wymer, J. J., 2006. Quaternary, ice sheets and their legacy. In: Brenchley, P.J., Rawson, P.F. (Eds.), The Geology of England and Wales, second ed. The Geological Society, London, pp. 429-467.

Cornish, R., 1981. Glaciers of the Loch Lomond Stadial in the western southern Uplands. Proceedings of the Geologists' Association 92, 105-114.
Ditchburn, R.G., Whitehead, N.E., 1994. The separation of ${ }^{10} \mathrm{Be}$ from silicates. In: Hancock, G., Wallbrink, P. (Eds.), Third Workshop of the South Pacific Environmental Radioactivity Association. Australian National University, Canberra, pp. $4-7$.

Dunai, T.J., 2001. Influence of secular variation of the magnetic field on production rates of in situ produced cosmogenic nuclides. Earth and Planetary Science Letters 176, 157-169.

Evans, D.J.A., Ó Cofaigh, C., 2003. Depositional evidence for marginal oscillations of the Irish Sea Ice Stream in southern Ireland during the last glaciation. Boreas 32, 76-101.

Evans, D.J.A., Livingstone, S.J., Vieli, A., Ó Cofaigh, C., 2009. The palaeoglaciology of the central sector of the British and Irish Ice Sheet: reconciling glacial geomorphology and preliminary ice sheet modeling. Quaternary Science Reviews 28, 740-758.

Fifield, L.K., Tims, S.G., Fujioka, T., Hoo, W.T., Everett, S.E., 2010. Accelerator mass spectrometry with the 14UD accelerator at the Australian National University. Nuclear Instruments and Methods B 268, 858-862.

Gosse, J.C., Phillips, F.M., 2001. Terrestrial in situ cosmogenic nuclides: theory and application. Quaternary Science Reviews 20, 1475-1560.

Haapaniemi, A.I., Scourse, J.D., Peck, V.L., Kennedy, H., Kennedy, P., Hemming, S.R. Furze, M.F.A., Pieńkowski, A.J., Austin, W.E.N., Walden, J., Wadsworth, E., 2010. Source, timing, frequency and flux of ice-rafted detritus to the Northeast Atlantic margin, 30-12 ka: testing the Heinrich precursor hypothesis. Boreas. doi:10.1111/j.1502-3885.2010.00141.

Hiemstra, J.F., Rijsdijk, K.F., Evans, D.J.A., van der Meer, J.J.M., 2005. Integrated micro- and macro-scale sediment analyses of Irish Sea diamicts from Abermawr and Traeth y Mwnt. Boreas 34, 61-74.

Hiemstra, J.F., Evans, D.J.A., Scourse, J.D., Furze, M.F.A., McCarroll, D., Rhodes, E., 2006. New evidence for a grounded Irish Sea glaciation of the Isles of Scilly, U.K. Quaternary Science reviews 25, 299-309.

Hubbard, A., Bradwell, T., Golledge, N., Hall, A.M., Patton, H., Sugden, D.E., Cooper, R., Stoker, M., 2009. Dynamic cycles, ice streams and their impact on the extent, chronology and deglaciation of the British-Irish ice sheet. Quaternary Science Reviews 28, 758-776.

Kohl, C.P., Nishiizumi, K., 1992. Chemical isolation of quartz for measurement of insitu-produced cosmogenic nuclides. Geochimica et Cosmochimica Acta 56, 3583-3587.

Lal, D., 1991. Cosmic ray labeling of erosion surfaces: in situ nuclide production rates and erosion models. Earth and Planetary Science Letters 104, 424-439.

Lifton, N., Bieber, J., Clem, J., Duldig, M., Evenson, P., Humble, J., Pyle, R., 2005. Addressing solar modulation and long-term uncertainties in scaling secondary cosmic rays for in situ cosmogenic nuclide applications. Earth and Planetary Science Letters 239, 140-161.

Liu, B., Phillips, F.M., Fabryka-Martin, J.T., Fowler, M.M., Stone, W.D., 1994. Cosmogenic ${ }^{36} \mathrm{Cl}$ accumulation in unstable landforms 1 . Effects of the thermal neutron distribution. Water Resources Research 30, 3115-3125.

Lowe, J.J., Rasmussen, S.O., Björk, S., Hoek, W.Z., Steffensen, J.P., Walker, M.J.C., Yu, Z. C., INTIMATE group, 2008. Synchronization of palaeoenvironmental events in the North Atlantic Region during the last termination: a revised protocol recommended by the INTIMATE group. Quaternary Science Reviews 27, 6-17.

McCabe, A.M., 2008. Glacial Geology and Geomorphology: The Landscapes of Ireland. Dunedin Academic Press, Edinburgh, 274 pp.

McCabe, A.M., Ó Cofaigh, C., 1996. Upper Pleistocene facies sequences and relative sea-level trends along the south coast of Ireland. Journal of Sedimentary Research 66, 376-390.

McCabe, A.M., Clark, P.U., Clark, J., 2005. AMS ${ }^{14} \mathrm{C}$ dating of deglacial events in the Irish Sea Basin and other sectors of the British-Irish ice sheet. Quaternary Science Reviews 24, 1673-1690.

McCabe, A.M., Clark, P.U., Clark, J., Dunlop, P., 2007. Radiocarbon constraints on readvances of the British-Irish ice sheet in the northern Irish Sea basin during the last deglaciation. Quaternary Science Reviews 26, 1204-1211.

McCarroll, D., 2001. Deglaciation of the Irish Sea basin, a critique of the glaciomarine hypothesis. Journal of Quaternary Science 16, 393-404.

McCarroll, D., Ballantyne, C.K., 2000. The last ice sheet in Snowdonia. Journal of Quaternary Science 15, 765-778.

Nicholson, D.T., 2009. Holocene Microweathering Rates and Processes on Iceeroded Bedrock, Røldal Area, Hardandangervidda, Southern Norway. In: Geological Society, London, Special Publication, vol. 320, pp. 29-49.

Ó Cofaigh, C., Evans, D.J.A., 2001a. Deforming bed conditions associated with a major ice stream of the last British ice sheet. Geology 29, 795-798.

Ó Cofaigh, C., Evans, D.J.A., 2001b. Sedimentary evidence for deforming bed conditions associated with a grounded Irish Sea glacier, southern Ireland. Journal of Quaternary Science 16, 435-454.

Ó Cofaigh, C., Evans, D.J.A., 2007. Radiocarbon constraints on the age of the maximum advance of the British-Irish ice sheet in the Celtic sea. Quaternary Science Reviews 26, 1197-1203.

Peltier, W.R., Fairbanks, R.G., 2006. Global glacial ice volume and Last Glacial Maximum duration from an extended Barbados sea level record. Quaternary Science Reviews 25, 3322-3337.

Phillips, F.M., Stone, W.D., Fabryka-Martin, J., 2001. An improved approach to calculating low-energy cosmic ray neutron fluxes near the land/atmosphere interface. Chemical Geology 175, 689-701.

Roberts, D.H., Dackombe, R.V., Thomas, G.S.P., 2007. Palaeo-ice streaming in the central sector of the British-Irish Ice Sheet during the Last Glacial Maximum: evidence from the northern Irish Sea Basin. Boreas 36, 115-129. 
Scourse, J.D., 1991. Late Pleistocene stratigraphy and palaeobotany of the Isles of Scilly. Philosophical Transactions of the Royal Society of London B334, 405-448.

Scourse, J.D., Furze, M.F.A., 2001. A critical review of the glaciomarine model for Irish Sea deglaciation: evidence from southern Britain, the Celtic shelf and adjacent continental slope. Journal of Quaternary Science 16, 419-434.

Scourse, J.D., Austin, W.E.N., Bateman, R.M., Catt, J.A., Evans, C.D.R., Robinson, J.E., Young, J.R., 1990. Sedimentology and Micropalaeontology of Glacimarine Sediments from the Central and Southwestern Celtic Sea. In: Special Publications of the Geological Society of London, vol. 53, pp. 329-347.

Scourse, J.D., Hall, I.R., McCave, I.N., Young, J.R., Sugdon, C., 2000. The origin of Heinrich layers: evidence from $\mathrm{H} 2$ for European precursor events. Earth and Planetary Science Letters 182, 187-195.

Scourse, J.D., Evans, D.J.A., Hiemstra, J., McCarroll, D., Rhodes, E., Furze, M.A., 2006. Pleistocene stratigraphy, geomorphology and geochronology. In: Scourse, J.D. (Ed.), The Isles of Scilly, Field Guide. Quaternary Research Association, London, pp. 13-22.

Scourse, J.D., Haapaniemi, A.I., Colmenero-Hidalgo, E., Peck, V., Hall, I.R., Austin, W.E. N., Zahn, R., 2009. Growth, dynamics and deglaciation of the last British-Irish ice sheet: the deep-sea ice-rafted detritus record. Quaternary Science Reviews 28, 3066-3084

Sejrup, H.P., Hjelstuen, B.O., Dahgren, K.I.T., Haflidason, H., Kuijpers, A., Nygard, A., Praeg, D., Stoker, M.S., Vorren, T.O., 2005. Pleistocene glacial history of the NW European continental margin. Marine and Petroleum Geology 22 1111-1129.

Sissons, J.B., 1980. The Loch Lomond advance in the Lake District, northern England. Transactions of the Royal Society of Edinburgh: Earth Sciences 71, 13-27.

Smith, B.W., Rhodes, E.J., Stokes, S., Spooner, N.A., Aitken, M.J., 1990. Optical dating of sediments: initial quartz results from Oxford. Archaeometry 32, 19-31.
Stone, J.O., 2001. Unpublished University of Washington Cosmogenic Nuclide Laboratory method available for download at, http://depts.washington.edu/ cosmolab/chem.html.

Stone, J.O., 2004. Al, Be Separation from Quartz. Unpublished University of Washington Cosmogenic Nuclide Laboratory method available for download at http://depts.washington.edu/cosmolab/chem.html.

Stone, J.O., Ballantyne, C.K., 2006. Dimensions and deglacial chronology of the Outer Hebrides ice cap, northwest Scotland: implications of cosmic ray exposure dating. Journal of Quaternary Science 21, 75-84.

Stone, J.O., Allan, G.L., Fifield, L.K., Cresswell, R.G., 1996. Cosmogenic chlorine-36 from calcium spallation. Geochimica et Cosmochimica Acta 60, 679-692.

Thomas, G.S.P., Chiverrell, R.C., 2007. Structural and depositional evidence for repeated ice-marginal oscillation along the eastern margin of the Late Devensian Irish Sea Ice Stream. Quaternary Science Reviews 26, 2375-2405.

Thomas, G.S.P., Summers, A.J., 1983. The Quaternary stratigraphy between Blackwater Harbour and Tinnaberna, County Wexford. Journal of Earth Sciences Royal Dublin Society 5, 121-134.

Thomas, G.S.P., Summers, A.J., 1984. Glacio-dynamic structures from the Blackwater formation, Co. Wexford, Ireland. Boreas 13, 5-12.

Thomas, G.S.P., Chiverrell, R.C., Huddart, D., 2004. Ice-marginal depositional responses to readvance episodes in the Late Devensian glaciations of the Isle of man. Quaternary Science Reviews 23, 85-106.

Walker, M.J.C., McCarroll, D. (Eds.), 2001. The Quaternary of West Wales: Field Guide. Quaternary Research Association, London 184pp.

Wintle, A.G., 1981. Thermoluminescence dating of late Devensian loesses in southern England. Nature 289, 479-480.

Young, T., Gibbons, W., McCarroll, D., 2002. Geology Of The Country Around Pwllheli. Memoir Of The British Geological Survey, Sheet 134 (England and Wales). HMSO, London. 